\title{
Prevalence of Hepatitis A Virus (HAV) and Hepatitis E Virus (HEV) In the Patients Presenting With Acute Viral Hepatitis at a Tertiary Care Hospital, Rajkot, Western India
}

\author{
Dr. Nirali Daftary ${ }^{1 *}$, Dr. Dipika Patel ${ }^{2}$ \\ ${ }^{1}$ Assistant Professor, Microbiology Department, P.D.U Govt Medical College, Rajkot, "JANANI", Nutan nagar society-2, Block \\ no.42, Opp. Kotecha Chowk, Kalawad Road, Rajkot-360001, Gujarat, India \\ ${ }^{2}$ Tutor, Microbiology Department, Govt Medical College, Surat, 75/B, Dharanagar Society, Abrama, Valsad- 396002, Gujarat, India
}

DOI: $10.36348 /$ sjpm.2021.v06i01.005

| Received: 21.12.2020 | Accepted: 05.01.2021 | Published: 09.01.2021

*Corresponding author: Dr. Nirali Daftary

\section{Abstract}

Acute viral hepatitis (AVH) is a systemic infection affecting the liver predominantly. It is a major public health problem in India and other developing nations having inadequate sanitary conditions. This study was undertaken to determine the trends of Hepatitis A \& E \& their coinfection in a tertiary care hospital so that appropriate management of cases as well as prevention can be planned. Material \& Methods: Over a 1-year period, a total of 1074 serum samples were collected from clinically suspected cases of hepatitis. The serum samples were screened for IgM anti-HAV and IgM anti-HEV. Seasonal variation \& age group wise seropositivity of hepatitis A\& E was studied. Results: Out of the total 1074 samples screened, the percentage positivity of Hepatitis A was $6 \%$ and Hepatits E was $15 \%$ respectively. Of both Hepatitis A \& E positive cases, males outnumbered females. Majority of HAV positive cases were children whereas majority of hepatitis E positive cases were adults. Conclusion: The prevalence of HEV was more than HAV in enterically transmitted viruses, making them a major public health problem in our area. Seasonal trends of infection were observed in addition, coinfection though infrequent, but still detected in one case.

Keywords: Acute viral hepatitis (AVH), liver predominantly, HEV, IgM anti-HEV.

Copyright (C) 2021 The Author(s): This is an open-access article distributed under the terms of the Creative Commons Attribution 4.0 International License (CC BY-NC 4.0) which permits unrestricted use, distribution, and reproduction in any medium for non-commercial use provided the original author and source are credited.

\section{INTRODUCTION}

Acute viral hepatitis (AVH) is a systemic infection affecting the liver predominantly. It is a major public health problem in India and other developing nations having inadequate sanitary conditions which associated with substantial morbidity and mortality. Hepatitis A and Hepatitis E are both enterically transmitted virus infections resulting in sporadic and epidemic forms. Both these viruses do not cause chronic hepatitis. India is hyperendemic for HAV and HEV. The anti-hepatitis A virus (HAV) seroprevalence rate is presently decreasing in many parts of the world. Several factors contribute to the decline of the infection rate, including rising socioeconomic levels, increased access to clean water and the availability of a hepatitis A vaccine. The illness due to HAV is age related, whereas HEV occurring during pregnancy results in high mortality. Fulminant hepatic failure is higher in coinfections of A and E, than in single infection. Since, $\mathrm{HAV}$ and HEV are spread through feco-oral route the infection rate is expected to be similar. Therefore, this study was undertaken to determine the trends of
Hepatitis A \& E \& their co-infection in a tertiary care hospital so that appropriate management of cases as well as prevention can be planned.

\section{MATERIAL\& METHODS}

Over a 1-year period, a total of 1074 serum samples (HAV - $532 \mathrm{HEV} \mathrm{-} \mathrm{542)} \mathrm{were} \mathrm{collected} \mathrm{from}$ clinically suspected cases of hepatitis. The serum samples were screened for IgM anti-HAV and IgM anti-HEV using ELISA (Enzyme Linked Immunosorbent Assay) kits. Cases were categorized into two groups - children (18 years) and adults (>18 years).

\section{RESULTS}

Out of the total 1074 samples screened, 65 samples were positive for anti HAV IgM and 161 were positive for anti HEV IgM. The percentage positivity of Hepatitis A was $6 \%$ and Hepatits E was $15 \%$. Coinfection of hepatitis A\& $\mathrm{E}$ was seen in 1 case in October. Of both Hepatitis A \& E positive cases, males $(61 \%)$ outnumbered females $(39 \%)$. Majority of HAV positive cases were children whereas majority of 
hepatitis E positive cases were adults. Higher seropositivity of hepatitis A infection was observed in monsoon season and for hepatitis E infection maximum cases were seen in summer \& in monsoon. Seasonal variation of hepatitis $\mathrm{A}$ and hepatitis $\mathrm{E}$ is depicted in Figure-4.

\section{DISCUSSION}

Viral hepatitis is a major public health problem throughout the world. This is a serious problem in India also and has been reported from all parts of this country. In our study among the two enterically transmitted viruses, the prevalence of HEV was more than HAV. Prevalence of hepatitis A was $6 \%$ \& of hepatitis $\mathrm{E}$ was $15 \%$, whereas higher prevalence of hepatitis $\mathrm{A}(33 \%, 32 \%, 26.9 \%, 4,5,1,64,614.6 \%)$ and hepatitis $\mathrm{E}(37.4 \%, 45.4 \%)$ was reported by various authors.

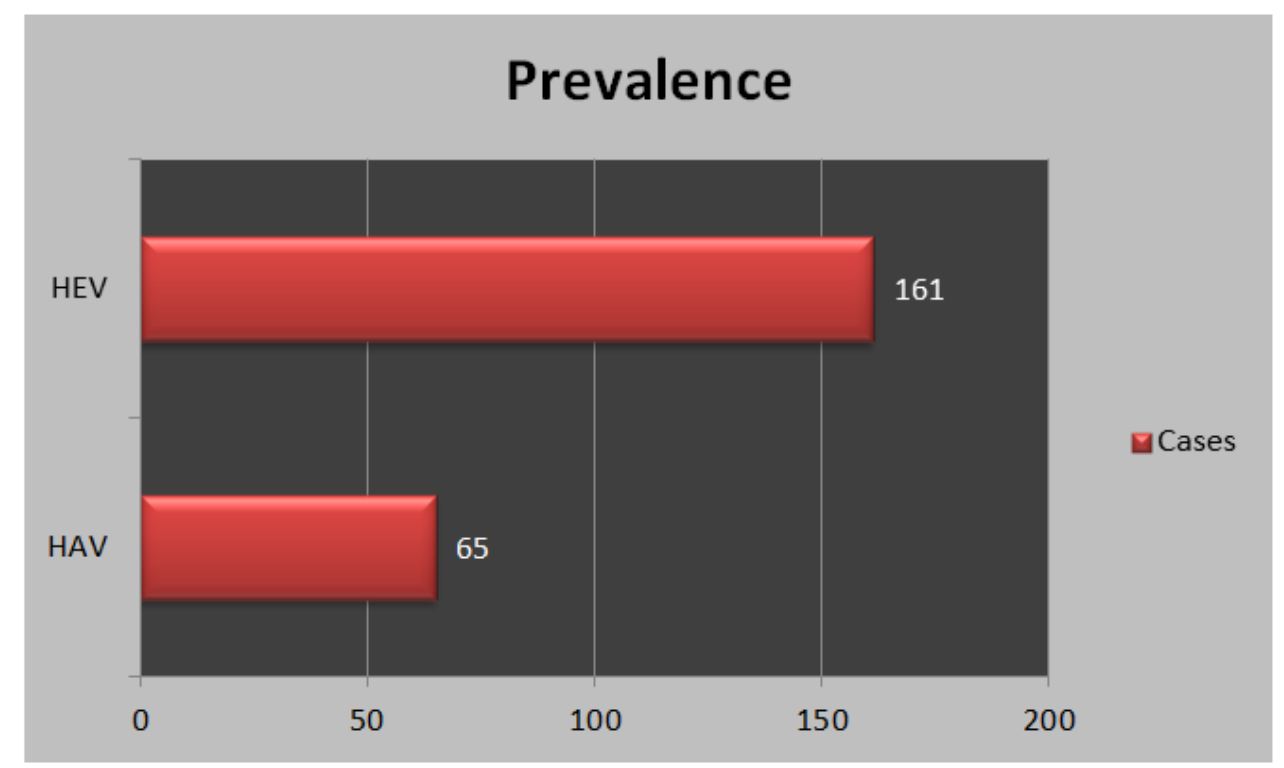

Fig-1

In contrast to our study low seroprevalence of hepatitis $\mathrm{E}(7 \%)$ was reported in a 5 community based study from Alwar while comparable results (17.9\%) were reported by Gupta $S$ et al., [1] In our study, coinfection of Hepatits A \& E was seen in 1 case in contrast to study by Subrat et al., [2] who found no case of coinfection whereas higher percentage $(16 \%)$ of 1 coinfection was reported in literature.

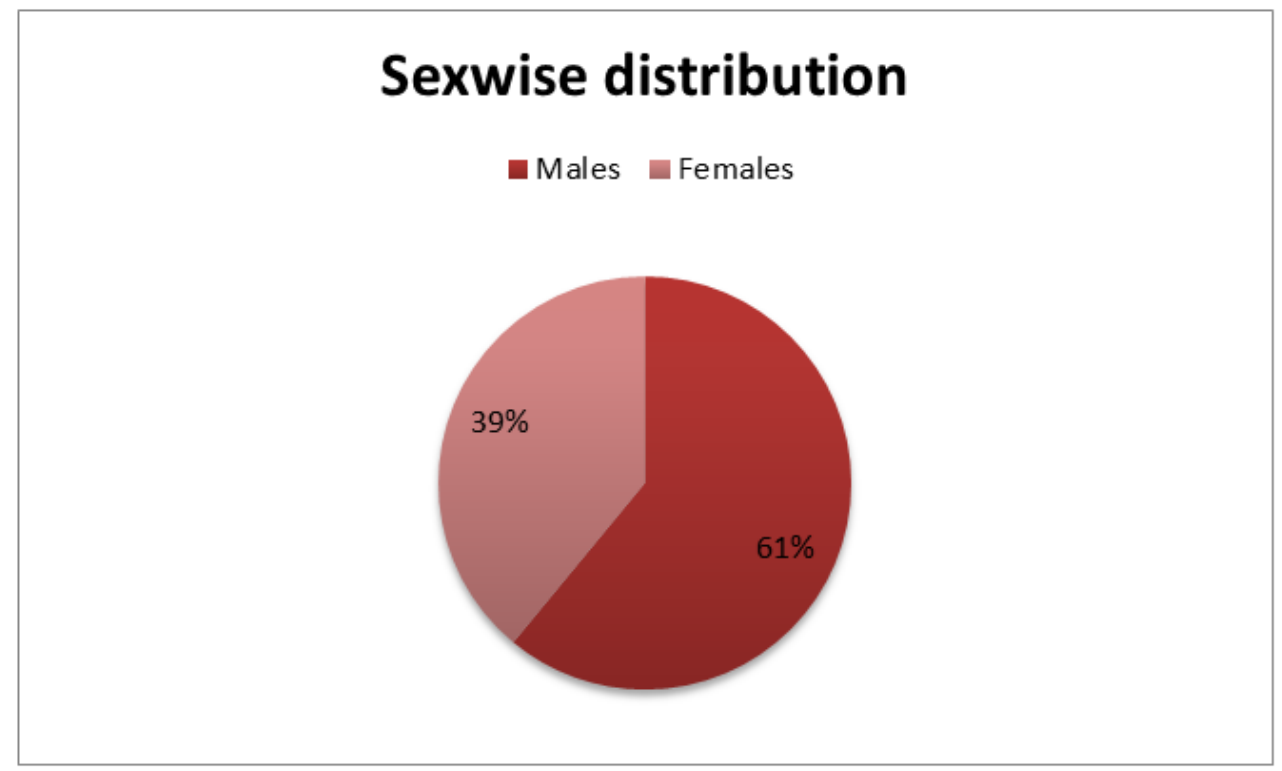

Fig-2

Overall incidence of enteric viral hepatitis was more in males than females from our hospital and similar results were reported from various studies. 


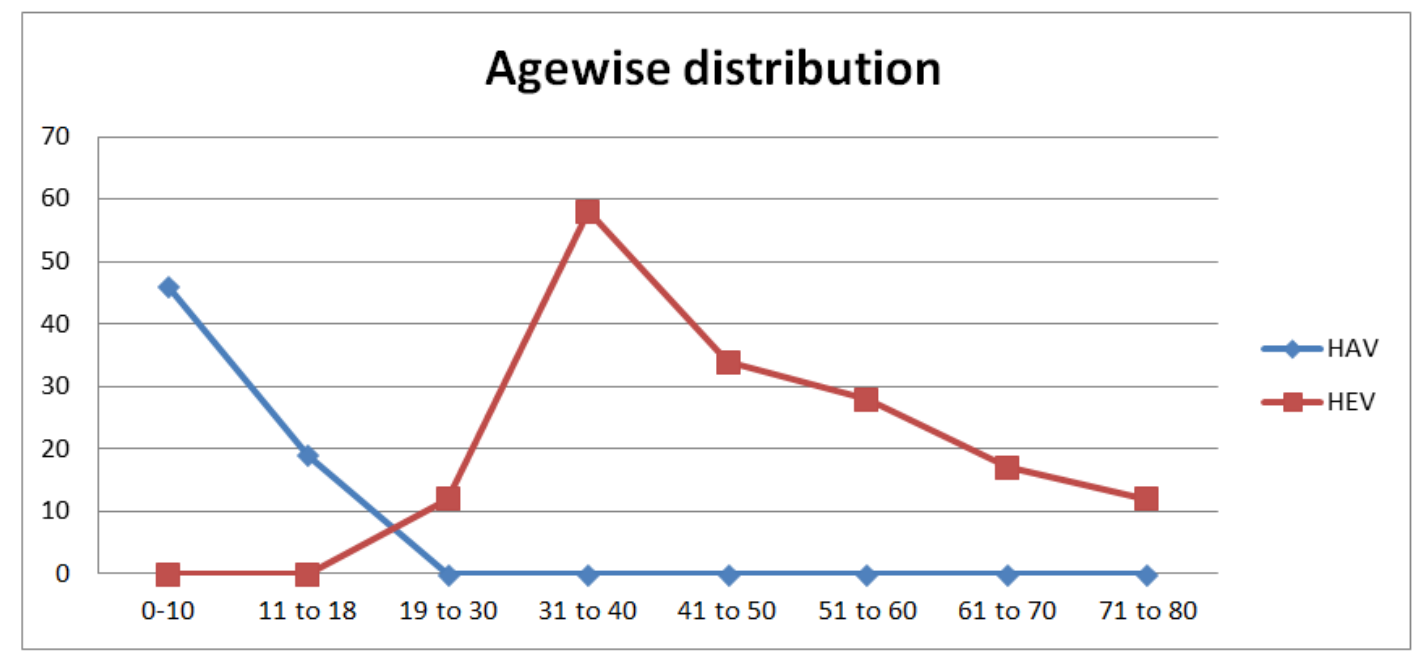

Fig-3

In our study hepatitis A positivity was found more in children but hepatits E seropositivity was found more in adults which is similar to hospital based study from North India. Hepatitis A \& E are endemic and infection occurred throughout the year but seasonal variation was observed.

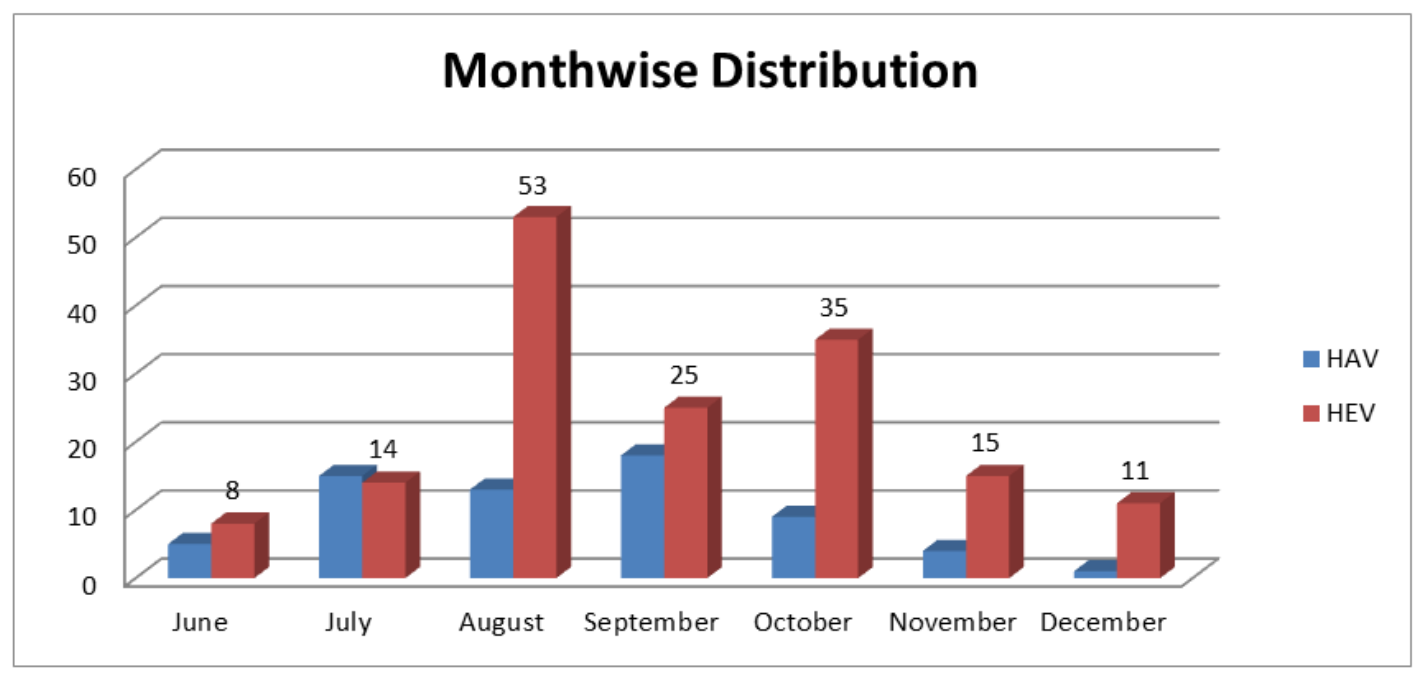

Fig-4

In our hospital Hepatitis A infection was more prevalent in monsoon which was similar to study of 5,7 Singh et al., [3] Hepatitis E infection was found common in summer \& monsoon season which is similar to Ippagunta et al., [4], Gupta S et al., [1] observed two seasonal peaks (Feb-May, December) of hepatitis A\& E.

\section{CONCLUSION}

To conclude prevalence of hepatitis $\mathrm{E}$ was more than hepatitis A in enterically transmitted viruses, making them a major public health problem in our area. Seasonal trends of infection were observed in addition, coinfection though infrequent, but still detected in one case. Adequate supplies of safe drinking water and proper disposal of sewage, combined with personal hygiene practices, such as regular hand washing, reduce the spread of enteric hepatitis.

\section{REFERENCES}

1. Jain, P., Prakash, S., Gupta, S., Singh, K. P., Shrivastava, S., Singh, D. D., ... \& Jain, A. (2013). Prevalence of hepatitis A virus, hepatitis B virus, hepatitis $C$ virus, hepatitis $D$ virus and hepatitis $E$ virus as causes of acute viral hepatitis in North India: A hospital based study. Indian journal of medical microbiology, 31(3), 261-265.

2. Kumar, S., Ratho, R. K., Chawla, Y. K., \& Chakraborti, A. (2007). The incidence of sporadic viral hepatitis in North India: a preliminary study. Hepatobiliary \& pancreatic diseases international: HBPD INT, 6(6), 596-599.

3. Singh, J., Prakash, C., Gupta, R. S., Bora, D., Jain, D. C., \& Datta, K. K. (1997). Epidemiology of endemic viral hepatitis in an urban area of India: a retrospective community study in Alwar. Bulletin of the World Health Organization, 75(5), 463-468. 
4. Ippagunta, S. K., Naik, S., Sharma, B., \& Aggarwal, R. (2007). Presence of hepatitis E virus in sewage in Northern India: frequency and seasonal pattern. Journal of medical virology, 79(12), 1827-1831.

5. Acharya, S. K., Batra, Y., \& Bhatkal, B. (2003). Sero epidemiology of hepatitis A virus infection among school children in Delhi; implications for HAV vaccination. J gastroenterol Hepatol, 18, 822-7.

6. Mohanavalli, B., Dhevahi, E., Menon, T., Malathi, S., \& Thyagarajan, S. P. (2003). Prevalence of antibodies to hepatitis $\mathrm{A}$ and hepatitis $\mathrm{E}$ virus in urban school children in Chennai. Indian pediatrics, 40(4), 328-331.

7. Nandi, B., Hadimani, P., Arunachalam, R., \& Ganjoo, R. K. (2009). Spectrum of acute viral hepatitis in Southern India. Medical Journal Armed Forces India, 65(1), 7-9.

8. Suri, P., Chhina, D., Gupta, V., Singh, J., Chopra, P., \& Singh, R. (2012). Seroprevalence of
Parenterally and Enterallt transmitted hepatitis viruses in a tertiary care hospital of North India- A two year study. J of Gastro infs. 2;46-51.

9. Jacobsen, K. H., \& Koopman, J. S. (2004). Declining hepatitis A seroprevalence: a global review and analysis. Epidemiology \& Infection, 132(6), 1005-1022.

10. World Health Organization. (2000). Hepatitis A vaccines: WHO position paper. Wkly Epidemiol Rec. 75:38-443.

11. Braunwald, E., Fauci, A. S., Kasper, D. L., Hauser, S. L., Longo, D. L., \& Jameson, J. L. (2001). Harrison's Principles of Internal Medicine. 5th ed.; 1694-7104.

12. Joon, A., Rao, P., Shenoy, S. M., \& Baliga, S. (2015). Prevalence of hepatitis A virus (HAV) and hepatitis E virus (HEV) in the patients presenting with acute viral hepatitis. Indian journal of medical microbiology, 33(5), 102. 